\title{
Hydrographic changes in the tropical and extratropical Pacific during the last deglaciation
}

\author{
Laura Rodríguez-Sanz, ${ }^{1}$ P. Graham Mortyn, ${ }^{1,2}$ Juan C. Herguera, ${ }^{3}$ and Rainer Zahn ${ }^{1,4,5}$ \\ Received 15 May 2013; revised 22 August 2013; accepted 23 August 2013; published 18 September 2013.
}

[1] Fine-scale, paired $\mathrm{Mg} / \mathrm{Ca}-\delta^{18} \mathrm{O}$ profiles (Globigerinoides ruber white, sensu lato) from the San Lázaro Basin (SLB) at $25^{\circ} \mathrm{N}$ in the Northeast Pacific reveal a transition from a predominant presence of tropical/subtropical waters during the last glacial termination (T1) to an increasing influence of fresh and cold California Current waters toward the Holocene. Changing atmospheric circulation patterns over the Northeast Pacific in step with the demise of the Northern Hemisphere ice sheets and/or with a shift from El Niño- to La Niña-like conditions toward the Holocene are prime candidates to explain this water mass change. $\delta^{18} \mathrm{O}_{\mathrm{SW}-\mathrm{IVC}}$ increases of $\sim 0.5-0.7 \%$ during the Younger Dryas (YD) and Heinrich stadial 1 (HS1) at the SLB are observed in a number of $\delta^{18} \mathrm{O}_{\mathrm{SW}-\mathrm{IVC}}$ records from the tropical Pacific, more directly influenced by changes in the position of the Intertropical Convergence Zone (ITCZ). Conditioning by ITCZ migration of the tropical Pacific Ocean towards salinity increase during YD and HS1, and the subsequent advection of those water masses as far north as $25^{\circ} \mathrm{N}$ likely accounted for the reconstructed hydrographical changes at the SLB. A larger influence of tropical water masses as far north as $25^{\circ} \mathrm{N}$ plausibly contributed to changes in the atmospheric moisture transports to western North America and affected the regional hydrological cycle across T1. Finally, the fine-scale resolution of our $\delta^{18} \mathrm{O}_{\mathrm{SW}-\mathrm{IVC}}$ record allows pinpointing a shift from relative salty to fresh surface conditions at $\sim 16.2 \mathrm{ka}$, signaling that the two-phase structure of HS1 is plausibly a ubiquitous feature of the northern tropical to extratropical ocean-atmosphere dynamics.

Citation: Rodríguez-Sanz, L., P. G. Mortyn, J. C. Herguera, and R. Zahn (2013), Hydrographic changes in the tropical and extratropical Pacific during the last deglaciation, Paleoceanography, 28, 529-538, doi:10.1002/palo.20049.

\section{Introduction}

[2] Paleoceanographic studies have provided evidence of the impacts, via atmospheric teleconnections, of North Atlantic climate fluctuations during the last glacial termination (hereafter T1, 19-10 ka, [Denton et al., 2010; Clark et al., 2012]) on distal areas of the Pacific Ocean. Stable oxygen isotope $\left(\delta^{18} \mathrm{O}\right)$ records from South American speleotherms [Wang et al., 2007], color reflectance from Cariaco Basin [Deplazes et al., 2013], and seawater $\delta^{18} \mathrm{O}$ $\left(\delta^{18} \mathrm{O}_{\mathrm{SW}-\mathrm{IVC}}\right)$ records from the Pacific Ocean [Rosenthal et al., 2003; Benway et al., 2006; Leduc et al., 2007; Steinke et al., 2008] collectively suggest a tight link between

\footnotetext{
${ }^{1}$ Institute of Environmental Science and Technology, Universitat Autònoma de Barcelona, Barcelona, Spain.

${ }^{2}$ Department of Geography, Universitat Autònoma de Barcelona, Barcelona, Spain.

${ }^{3}$ Center for Scientific Research and Higher Education, Ensenada, Mexico.

${ }^{4}$ Institució Catalana de Recera i Estudis Avançats, Barcelona, Spain. Spain.

${ }^{5}$ Department of Physics, Universitat Autònoma de Barcelona, Barcelona,

Corresponding author: L. Rodríguez-Sanz, Institute of Environmental Science and Technology, Universitat Autònoma de Barcelona, Bellaterra, Catalonia 08193, Spain. (Laura.Rodriguez@uab.cat; Laura.Rodriguez@anu.edu.au)

(C)2013. American Geophysical Union. All Rights Reserved. 0883-8305/13/10.1002/palo.20049
}

North Atlantic climate variability, changes in the mean latitudinal position of the Intertropical Convergence Zone (ITCZ), and tropical Pacific hydrography across T1. During millennial-scale North Atlantic cold events, such as the Younger Dryas (YD) and the Heinrich Stadial 1 (HS1), the ITCZ shifted southwards, most likely in response to the cooling in the Northern Hemisphere [Deplazes et al., 2013]. These changes plausibly reduced the net moisture transport between the Atlantic and Pacific Ocean [Benway et al., 2006; Leduc et al., 2007], weakened the East Asian Summer Monsoon [Yancheva et al., 2007], with the attendant surface ocean salinification throughout the tropical Pacific [Rosenthal et al., 2003; Benway et al., 2006; Leduc et al., 2007; Steinke et al., 2008].

[3] Along the northern California Margin, bioturbation indices [Behl and Kennett, 1996], planktonic foraminiferal abundances [Hendy and Kennett, 2000; Hendy, 2010], and sea surface temperature (SST) and $\delta^{18} \mathrm{O}_{\text {SW-IVC }}$ records spanning T1 and beyond [Seki et al., 2002; Pak et al., 2012] all mimic the Dansgaard-Oeschger variability of the Greenland ice cores [Dansgaard et al., 1993; North Greenland Ice Core Project (NGRIP), 2004]. Thunell and Mortyn [1995] documented the instability of the regional climate during the Last Glacial Maximum (LGM) and highlighted the link with North Atlantic climate, possibly in response to changes in the wind patterns tied to the maximum growth of the North American ice sheets [Cooperative 


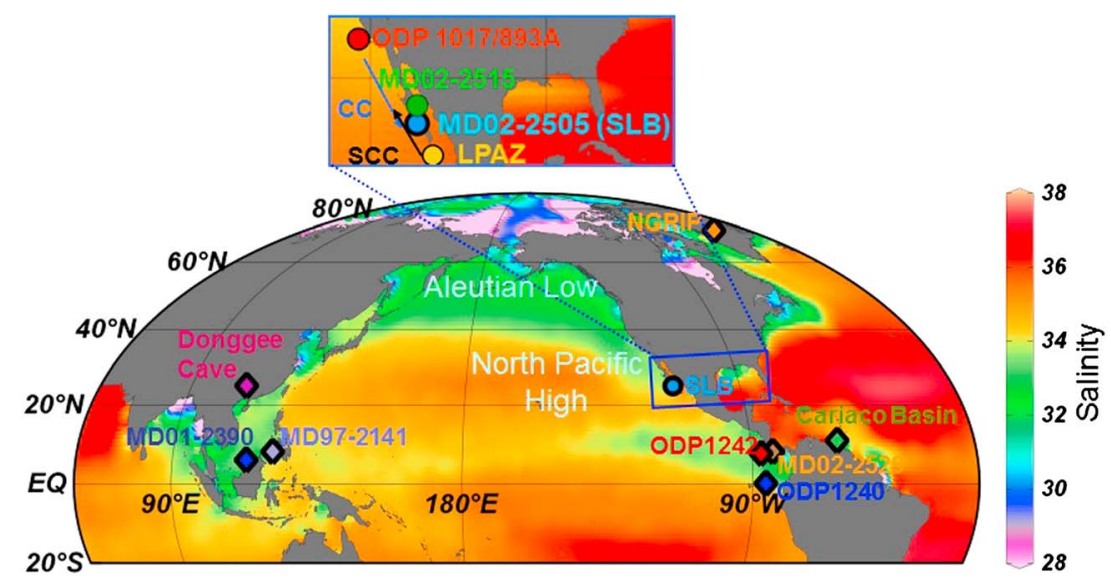

Figure 1. The upper panel shows the location of the MD05-2505 (light blue dot) core retrieved from the San Lázaro Basin (SLB) in the Pacific Ocean $\left(25^{\circ} \mathrm{N}, 112^{\circ} \mathrm{W}\right.$, and water depth $\left.535 \mathrm{~m}\right)$ and sediment cores used for comparison (green and red dots) in Figures 3a and 4. The extended map shows the SLB location together with the location of the cores used for comparison in Figures $3 \mathrm{~b}-3 \mathrm{~g}$. The base map depicts World Ocean Atlas 2005 modern summer sea surface salinity. Gray lines in the extended map show a schematic view of the ocean circulation patterns in the Northeast Pacific. Blue and dark arrows in both panels show the flow of the California Current and Southern California Countercurrent, respectively.

Holocene Mapping Project (COHMAP) members, 1988; Ganeshram and Pedersen, 1998; Cheshire et al., 2005]. Other studies have connected paleoclimatic and paleohydrographic changes in the Northeast Pacific to changes in the California Current strength, due to shifted wind pattern under glacial boundary conditions [e.g., Herbert et al., 2001; Hendy et al., 2004; Pak et al., 2012].

[4] At present, the pressure gradient between a low pressure cell that develops over the North American continent during boreal summer/spring (winter/fall) and a strengthened/northward (weakened/southward) position of the North Pacific High (NPH) intensifies (weakens) the meridional winds along the California margin which drive the California Current [Bakun, 1973]. The presence of the Laurentide and Cordillerean ice sheets during the LGM most likely developed a high-pressure cell over North America. This led to a reduction of the atmospheric land-ocean gradient, which decreased the meridional winds [COHMAP members, 1988], and in turn slowed the California Current [Lyle et al., 1992], accounting for most of the changes observed in the California Margin during the LGM [e.g., Herbert et al., 2001]. Other authors have linked the strength of the California Current to orbital changes in the precessional band [Robert, 2004; Yamamoto et al., 2007], as model simulations of El Niño Southern Oscillation (ENSO) [Clement et al., 1999] indicate in-phase relationships between NPH minima and spring perihelion.

[5] Recently, McClymont et al. [2012] provided a model simulation based on climate reconstructions from the Gulf of California, showing that T1 involved atmospheric reorganization patterns that preclude the use of modern patterns to interpret their data. In support of this, Lyle et al. [2012] showed evidence of changes in precipitation source to the western United States during T1, suggesting a major influence of tropical Pacific air masses as a precipitation source to the region. This contrasts with the notion that the positioning of the polar jet stream governed the regional hydrological changes during T1 [e.g. Asmerom et al., 2010]. Changes in the source of moisture to western North America across T1 could have been alternatively triggered by atmospheric changes that involved the weakening of the NPH, which allowed warmer waters to flow over the California Margin due to a weaker California Current [Robert, 2004; Lyle et al., 2010].

[6] In this sense, new reconstructions of surface ocean hydrography (temperature and salinity) from the California Margin are instrumental to better assess the development of atmospheric teleconnections between the North Atlantic and the Northeast Pacific during T1. We exploit the sensitivity of the San Lázaro Basin (SLB), also known as the Soledad Basin, to the interplay between the fresh and cold California Current waters [Lynn and Simpson, 1987] from the north and the warm and saltier California Countercurrent waters, which are fed by tropical water masses to the south of $21^{\circ} \mathrm{N}$ [Lynn and Simpson, 1987]. The relative intensities of both currents are coupled to the strength of the northerly winds, which in turn are driven by the pressure gradients associated with the NPH and thermal continental low [Checkley and Barth, 2009]. Additionally, hydrographic changes at SLB are highly sensitive to ENSO conditions, i.e., during El Niño events anomalous poleward circulation in the eastern limb of the subtropical gyre [Bograd and Lynn, 2001] allows the penetration of warm and saline subtropical waters into the California Margin, at the expense of the California Current [Durazo and Baumgartner, 2002]. Hence, by reconstructing the surface ocean hydrography developments at the SLB, which are associated with these ocean-atmosphere components, our study sheds light on the Northeast Pacific teleconnections during the last glacial-to-interglacial transition.

\section{Material and Methods}

\subsection{Sediment Core Location}

[7] Core MD02-2505 (25N, $112^{\circ} \mathrm{W}, 535 \mathrm{~m}$ water depth) was retrieved from SLB, along the Baja California Margin, 
in the southernmost oceanic sector that is influenced by the California Current System (Figure 1). Upwelling of nutrient-rich waters along the California Margin favors the relatively high primary productivity in SLB [Linacre et al., 2010], which contributes to the high sedimentation rates observed in the basin $\left(\sim 1 \mathrm{~m} \mathrm{ky}^{-1}\right)$. Sediments retrieved from SLB feature excellent carbonate preservation [Marchitto et al., 2010] and laminated sequences indicating suboxia, which intermittently suppressed bioturbation at the sea floor [van Geen et al., 2003]. These features collectively make the SLB an ideal paleoceanographic archive to investigate past variations in the strength of the California Current and Countercurrent at very high temporal resolution.

\subsection{Chronology}

[8] Chronology of core MD02-2505 is based on 9 Accelerator Mass Spectrometry radiocarbon $\left({ }^{14} \mathrm{C}\right)$ determinations at the Lawrence Livermore National Laboratory on a mixed assemblage of planktonic foraminiferal species (Table S1). ${ }^{14} \mathrm{C}$ ages were calibrated to calendar ages using the program Calib 6.0 and the Marine09 calibration [Reimer et al., 2009] curve by applying a local reservoir age correction $(\Delta \mathrm{R})$ of $200 \pm 100$ years [Berger et al., 1966] to the average global ocean reservoir of 400 years. In order to develop the full chronology, the ages between available ${ }^{14} \mathrm{C}$ dates were interpolated and the mean sedimentation rate was then extrapolated for the section of the record younger than 6923 years B.P. $(663 \mathrm{~cm})$. According to our chronology sediment levels ranging from 2112 to $295 \mathrm{~cm}$ depth (used in this study) span the interval from the LGM and the subsequent transition (T1) into the late Holocene, i.e. from 19 to $3 \mathrm{ka}$. The age model indicates sedimentation rates at the core site of $1 \mathrm{mky}^{-1}$ (Figure S1 in the supporting information) across the entire time span, which at a sampling interval of $5 \mathrm{~cm}$ yields a temporal resolution of up to $\sim 50$ years between samples.

\subsection{Globigerinoides ruber $\mathrm{Mg} / \mathrm{Ca}$ Reconstructions}

[9] The abundance of the planktonic foraminiferal species selected for this study in MD02-2505 was very variable, ranging from intervals of moderate abundance to intervals of virtual absence of the selected species, likely associated with surface conditions (i.e., nutrient availability, temperature, salinity) precluding generation of continuous records for both $\mathrm{Mg} / \mathrm{Ca}$ and $\delta^{18} \mathrm{O}_{\mathrm{C}}$. We have established a threshold of a minimum of 15 specimens for paired $\mathrm{Mg} / \mathrm{Ca}-\delta^{18} \mathrm{O}_{\mathrm{C}}$ measurements; if a sample yielded less than 15 specimens, they were analyzed either for $\mathrm{Mg} / \mathrm{Ca}$ or $\delta^{18} \mathrm{O}_{\mathrm{C}}$, depending on the resolution of each of the two profiles across the specific interval of the records. For this study, we analyzed the morphotype sensu lato (s.l.) of the surface-dwelling, symbiont-bearing planktonic foraminifer G. ruber. This prevents any bias on paleoceanographic reconstructions caused by mixing the different morphotypes of $G$. ruber having potentially different habitats [Steinke et al., 2005]. G. ruber (s.l.) was picked from the size fraction $250-350 \mu \mathrm{m}$. Foraminiferal sample cleaning for $\mathrm{Mg} / \mathrm{Ca}$ analyses followed the Barker et al. [2003] cleaning protocol, with the reductive step included to remove ferromanganese (FeMn) coatings [Boyle, 1983]. Measurements to obtain calcium $\left[\mathrm{Ca}^{2+}\right]$, magnesium $\left[\mathrm{Mg}^{2+}\right]$, and other trace metal concentrations $[$ de Villiers et al., 2002; Yu et al., 2005] were performed using an Agilent 7500ce inductively coupled plasma-mass spectrometer (ICP-MS). Analytical precision was monitored calculating the relative standard deviation of two in-house standard solutions analyzed at five sample intervals, containing $\mathrm{Mg}$ / $\mathrm{Ca}=2.58$ and $\mathrm{Mg} / \mathrm{Ca}=7.73 \mathrm{mmol} \mathrm{mol}^{-1}$ at a $\left[\mathrm{Ca}^{2+}\right]$ of $40 \mathrm{ppm}$. The relative standard deviation was on average $2 \%$ $(N=45)$. A commonly used limestone standard (ECRM7521) with a specified $\mathrm{Mg} / \mathrm{Ca}$ of $3.75 \mathrm{mmol} \mathrm{mol}^{-1}$ [Greaves et al., 2008] was also analyzed, yielding values of $3.70 \pm 0.09 \mathrm{mmol}^{\mathrm{mol}}{ }^{-1}$. The calibration used to convert G. ruber $\mathrm{Mg} / \mathrm{Ca}$ into temperature was that of Dekens et al. [2002], without including water depth correction, which has been demonstrated to accurately reproduce summer temperatures at the same site [Mortyn et al., 2011]. A full error propagation exercise suggests uncertainties of $\pm 1^{\circ} \mathrm{C}$ associated with our SST reconstructions.

\subsection{Stable Oxygen Isotope $\left(\delta^{18} \mathrm{O}_{\mathrm{C}}\right)$ Measurements and Seawater Oxygen Isotope $\left(\delta^{18} \mathrm{O}_{\mathrm{Sw}}\right)$ Calculation}

[10] For the $\delta^{18} \mathrm{O}$ analyses, foraminiferal samples were rinsed with methanol, sonicated for $\sim 10 \mathrm{~s}$, and then oven dried at $40^{\circ} \mathrm{C}$. The $\delta^{18} \mathrm{O}_{\mathrm{C}}$ measurements were performed on a Thermofinnigan MAT253 mass spectrometer coupled to a Kiel IV device for $\mathrm{CO}_{2}$ sample gas preparation. External reproducibility $(1 \sigma)$ of carbonate standards was better than $\pm 0.06 \%$ for $\delta^{18} \mathrm{O}$. Isotope values were calibrated to the Vienna Peedee Belemnite scale with the National Bureau of Standards-19 and International Atomic Energy AgencyCO-1 carbonate standards.

[11] To correct for the temperature-controlled water-tocarbonate $\delta^{18} \mathrm{O}_{\mathrm{C}}$ fractionation in G. ruber and derive the seawater $\delta^{18} \mathrm{O}\left(\delta^{18} \mathrm{O}_{\mathrm{SW}}\right)$ profile, paired $\mathrm{Mg} / \mathrm{Ca}-\delta^{18} \mathrm{O}_{\mathrm{C}}$ measurements were conducted on two different aliquots of previously homogenized samples. The $\mathrm{Mg} / \mathrm{Ca}$-derived calcification temperatures of G. ruber from the Dekens et al. [2002] calibration were then used as input for the Orbulina universa low-light paleotemperature equation of Bemis et al. [1998] ( $T=16.5$ $\left.4.80 *\left(\delta^{18} \mathrm{O}_{\mathrm{C}}-\delta^{18} \mathrm{O}_{\mathrm{SW}}\right)\right)$ (Figure $\mathrm{S} 2$ ), which is commonly used for $G$. ruber [cf. Thunell et al., 1999]. The $\delta^{18} \mathrm{O}_{\mathrm{SW}}$ record was derived only from samples in which paired $\mathrm{Mg} / \mathrm{Ca}$ and $\delta^{18} \mathrm{O}_{\mathrm{C}}$ measurements were available. In order to correct for the global ice volume component of the $\delta^{18} \mathrm{O}_{\mathrm{SW}}$ signal, we used the "probabilistic sea level curve" computed on the basis of a suite of well dated and geographically distributed coral benchmarks by Stanford et al. [2011]. The sea level data were converted into mean ocean $\delta^{18} \mathrm{O}$ changes applying a $0.008 \%$ increase per meter of sea level lowering [Schrag et al., 2002] and were then subtracted from the $\delta^{18} \mathrm{O}_{\text {SW }}$ profile to obtain the local (ice volume corrected) $\delta^{18} \mathrm{O}_{\mathrm{SW}}\left(\delta^{18} \mathrm{O}_{\mathrm{SW}-\mathrm{IVC}}\right)$ that is discussed in our study. $\delta^{18} \mathrm{OSW}$ linearly relates to salinity at regional scales in the modern ocean [LeGrande and Schmidt, 2006]. Error propagation including $\delta^{18} \mathrm{O}$ analytical precision and SST-Mg/Ca calibration yielded $1 \sigma$ uncertainties for $\delta^{18} \mathrm{O}_{\text {SW-IVC }}$ of $\pm 0.3 \%$.

\section{Results}

[12] In order to place our data profiles into a context of Northern Hemisphere climate developments during T1, Figure 2 shows the Greenland $\delta^{18} \mathrm{O}$ record (Figure 2a) and our $\delta^{18} \mathrm{O}_{\mathrm{C}}$ (Figure 2b), the $\mathrm{Mg} / \mathrm{Ca}$-derived SST (Figure 2c), and the derived $\delta^{18} \mathrm{O}_{\text {SW-IVC }}$ (Figure 2d) reconstructions from the SLB. The G. ruber- $\delta^{18} \mathrm{O}_{\mathrm{C}}$ profile displays a gradual shift 


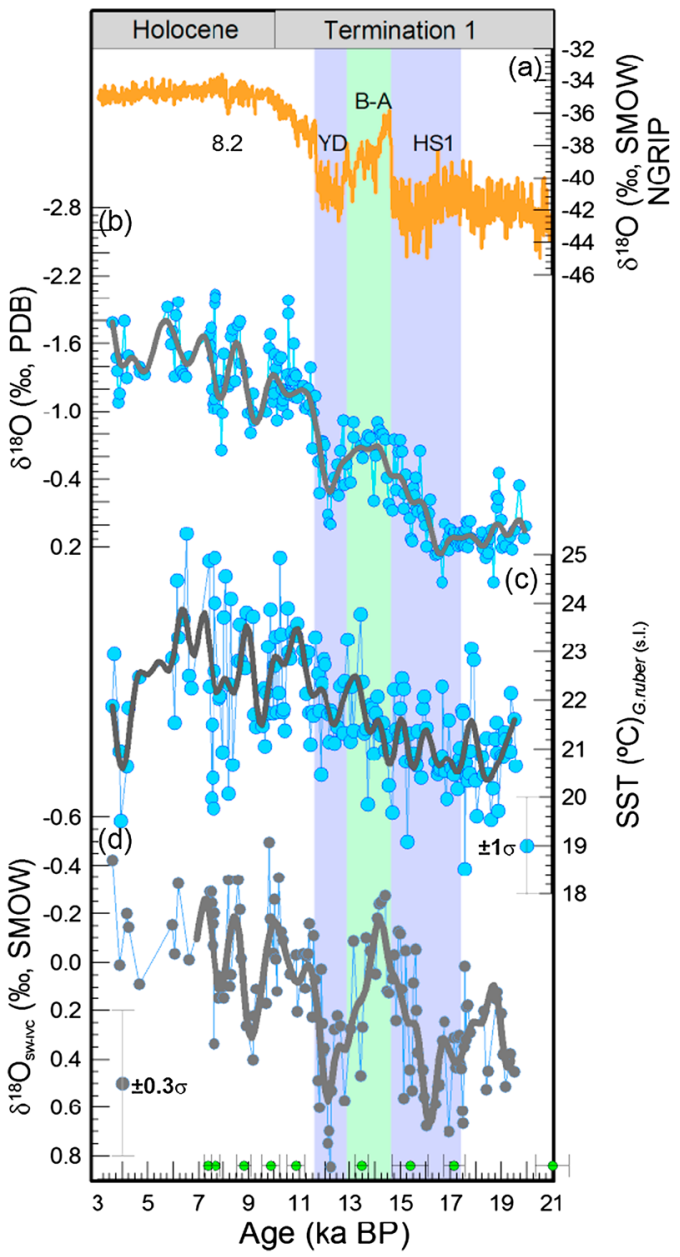

3.4
-3.2
-3.1
-2.9
-2.7
-2.5
-2.4
-2.2
-2.0
-1.8
1.7

Figure 2. (a) $\delta^{18} \mathrm{O}$ in the North Greenland Ice Core Project (NGRIP) ice core record of Greenland [NGRIP members, 2004]. Records from the San Lazaro Basin (SLB), core MD02-2505, using G. ruber (in a broad sense): (b) $\delta^{18} \mathrm{Oc}$ profile, (c) $\mathrm{Mg} / \mathrm{Ca}$-based $\mathrm{SST}$, and (d) local $\delta^{18} \mathrm{O}_{\mathrm{SW}-\mathrm{IVC}}$ changes at SLB, obtained by removing the ice volume (mean ocean ${ }^{18} \mathrm{O}_{\mathrm{SW}}$ ) [Stanford et al., 2011] and calcification temperature from the $\delta^{18} \mathrm{O}_{\mathrm{C}}$ measured on G. ruber (in a broad sense); note reversed $\delta^{18} \mathrm{O}_{\mathrm{SW}-\mathrm{IVC}}$ scale. Smoothing using a low-pass filter of 750 years is shown in gray in Figures $2 b-2 d$ to highlight the main trends. Light purple vertical-boxed areas denote the cold periods, Younger Dryas (YD) and Heinrich Stadial 1 (HS1). Light green verticalboxed area shows the Bølling-Allerød (B-A) interstadial in the Northern Hemisphere. Green dots denote the ${ }^{14} \mathrm{C}$ measurements and error bars used to build the MD02-2505 age model.

across T1 toward lighter values from $16.6 \mathrm{ka}$, interrupted by a millennial-scale increase at $12.4 \mathrm{ka}$ coinciding with YD. The overall $\delta^{18} \mathrm{O}_{\mathrm{C}}$ change $(\sim 1.6 \%)$ exceeds by $\sim 0.6 \%$ the mean ocean $\delta^{18} \mathrm{O}$ decrease [Schrag et al., 2002] attributable to the deglacial waning of Northern Hemisphere ice sheets. From $9.2 \mathrm{ka}$, the continuing trend toward lighter values was punctuated by periods of $G$. ruber- $\delta^{18} \mathrm{O}$ increases with a prime periodicity of $\sim 1.5 \mathrm{ky}$.

[13] Our SST profile (Figure 2c) shows a deglacial warming trend of $\sim 3^{\circ} \mathrm{C}$ and a distinct pattern of superimposed millennial-scale oscillations, having amplitude of up to $2^{\circ} \mathrm{C}$ and duration of $\sim 1.5$ to $2 \mathrm{ky}$. The Holocene is characterized by higher-amplitude SST swings, pointing to a more dynamic California Current towards the present, likely in response to solar activity variability [Marchitto et al., 2010].

[14] $\delta^{18} \mathrm{O}_{\text {SW-IVC }}$ (Figure 2d) as derived from G. ruber $\delta^{18} \mathrm{O}_{\mathrm{C}}$ and $\mathrm{Mg} / \mathrm{Ca}-\mathrm{SST}$ is punctuated by two pronounced increases $(\sim 0.5-0.7 \%$ o) at $\sim 16.2$ and $\sim 12.2 \mathrm{ka}$, coinciding with the HS1 and YD cold episodes in the North Atlantic (Figure 2a). These two $\delta^{18} \mathrm{O}_{\mathrm{SW}-\mathrm{IVC}}$ increases at SLB reflect salinification events followed by steep returns to fresher conditions at the onset of the B-A and early Holocene, respectively. These salinification events occurred in the absence of intense surface cooling at the SLB even though YD and HS1 were periods of extremely cold conditions in the Northern Hemisphere [Denton et al., 2010] and at $34^{\circ} \mathrm{N}$ [Pak et al., 2012]. Overall, the $\delta^{18} \mathrm{O}_{\text {SW-IVC }}$ record suggests that lower salinities were maintained throughout the Holocene (Figure 2c), which was punctuated by relatively minor salinity increases (barely exceeding the propagated $1 \sigma$ uncertainties, $0.3 \%$ o), e.g., at $\sim 9.1 \mathrm{ka}$ and $\sim 7.9 \mathrm{ka}$. In our SLB $\delta^{18} \mathrm{O}_{\mathrm{SW}-\mathrm{IVC}}$ reconstruction, the maximum at $16.2 \mathrm{ka}$ marks the start of the deglacial decreasing trend.

\section{Discussion}

\subsection{California Margin Hydrography Across T1 and the Holocene}

[15] In order to decipher the control exerted by the California Current and/or tropical water masses on the observed hydrographic changes at SLB across T1, we compare our data with previously published SST reconstructions [Herbert et al., 2001; Seki et al., 2002; Marchitto et al., 2010; Pak et al., 2012] along the California Margin between $\sim 19$ and $\sim 3 \mathrm{ka}$ (Figure 3a). We first focus on the SST developments in the SLB itself as reconstructed by our $G$. ruber $\mathrm{Mg} / \mathrm{Ca}$ data and the complementary Globigerina bulloides $\mathrm{Mg} / \mathrm{Ca}-\mathrm{SST}$ record of Marchitto et al. [2010] in nearby core MV99-GC41/PC14. We discuss them in the context of contemporaneous SST records from $G$. bulloides $\mathrm{Mg} / \mathrm{Ca}$ [Pak et al., 2012] and alkenone index $\left(U_{37}^{k}\right)$ [Seki et al., 2002] data at a site located further north $\left(34^{\circ} \mathrm{N}\right)$, which more prominently reflects the influence of the California Current [Checkley and Barth, 2009]. At present, northerly winds during spring and summer promote the influence of the California Current as far south as $25^{\circ} \mathrm{N}$ [Lynn and Simpson, 1987]. Comparing spring [Sautter and Thunell, 1991] derived from G. bulloides $\mathrm{Mg} / \mathrm{Ca}$ [Marchitto et al., 2010; Pak et al., 2012] and summer SST [Mortyn et al., 2011] from $G$. ruber $\mathrm{Mg} / \mathrm{Ca}$ (this study) provides insights into the role of the California Current on the hydrographic changes documented in the SLB records. On the other hand, it can be expected that the different seasonal preferences [e.g., Steinke et al., 2008] and/or the ability of the planktonic foraminifera to migrate throughout the upper water column in response to environmental stresses [Hendy, 2010] may undermine the comparison of SST reconstructions derived from different signal carriers, such as alkenones and foraminifera. We note, however, that this is unlikely the case for $U_{37}^{k}$ and $G$. ruber $\mathrm{Mg} / \mathrm{Ca}$ that in a down-core record from the eastern equatorial Pacific show remarkably similar trends [Leduc et al., 2007]. 

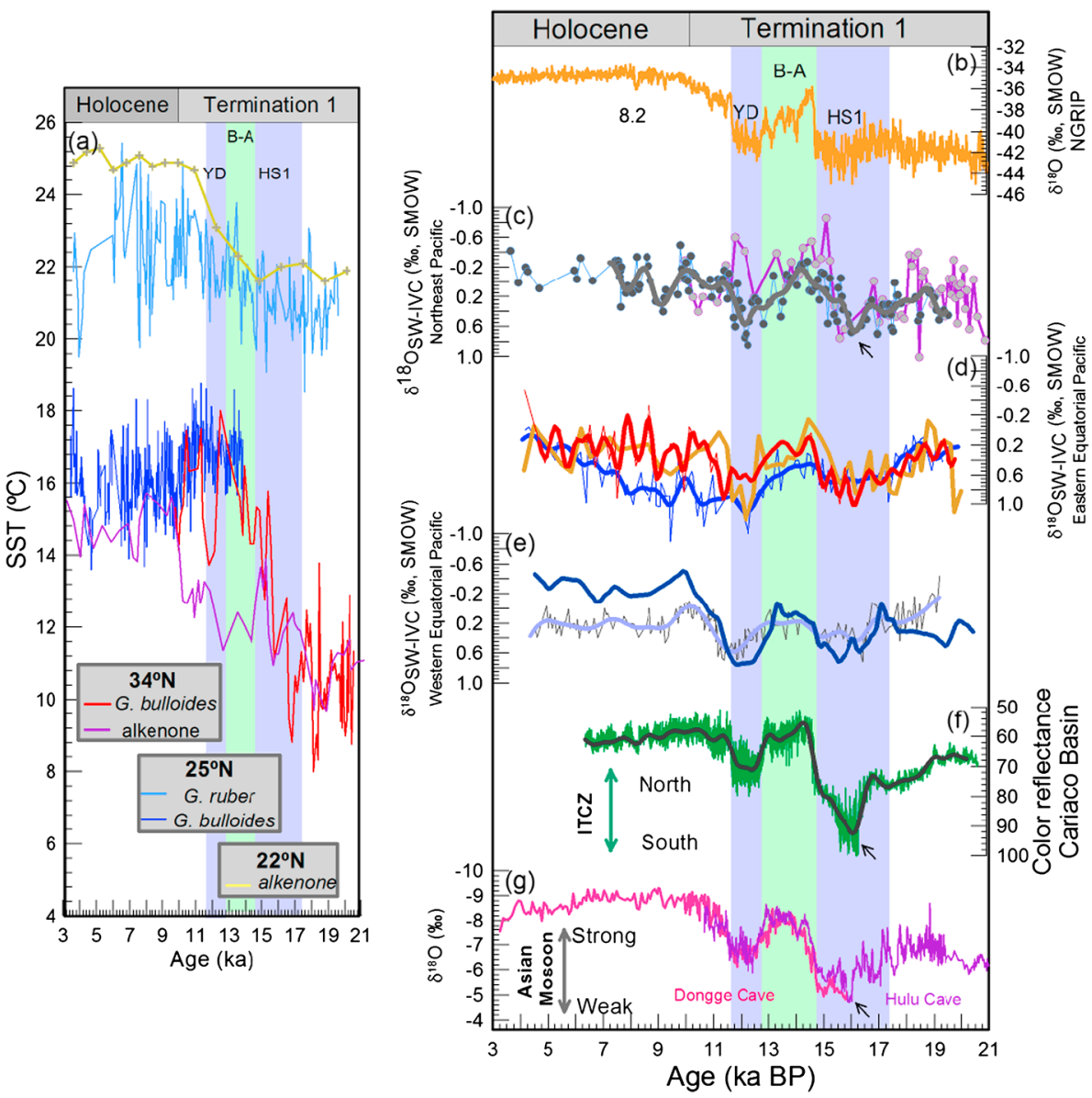

Figure 3. (a) Meridional Sea Surface Temperature (SST) changes along the California Margin: purple and red records correspond to alkenone-based [Seki et al., 2002] and $\mathrm{Mg} / \mathrm{Ca}-G$. bulloides [Pak et al., 2012] at $34^{\circ} \mathrm{N}$, respectively. Our G. ruber SST from MD02-2505 at $25^{\circ} \mathrm{N}$ is shown in light blue and the G. bulloides-SST record at the same core site [Marchitto et al., 2010] is shown in dark blue. We also display the alkenone-SST record at $22^{\circ} \mathrm{N}$ (yellow) [Herbert et al., 2001]. (b) $\delta^{18} \mathrm{O}$ in the NGRIP ice core record of Greenland is shown as reference [NGRIP members, 2004]. (c) Local $\delta^{18} \mathrm{O}_{\text {SW-IVC }}$ changes at MD02-2505 (light blue) overlain on the $\delta^{18} \mathrm{O}_{\text {SW-IVC }}$ record at $34^{\circ} \mathrm{N}$ (red) in the Northeast Pacific [Pak et al., 2012]; note reversed $\delta^{18} \mathrm{O}_{\text {SW-IVC }}$ scale. (d) Eastern equatorial Pacific $\delta^{18} \mathrm{O}_{\text {SW-IVC }}$ reconstruction from cores ODP1242 (red) [Benway et al., 2006], ODP1240 (blue) [Pena et al., 2008], and MD02-2529 (dark yellow) [Leduc et al., 2007]. (e) Western equatorial Pacific $\delta{ }^{18} \mathrm{O}_{\text {SW-IVC }}$ reconstructions from MD97-2141 (blue) [Rosenthal et al., 2003] and MD01-2590 (baby blue) [Steinke et al., 2008]. (f) Color reflectance from the Cariaco Basin [Deplazes et al., 2013]. (g) $\delta^{18} \mathrm{O}$ record from Dongge Cave (pink) [Yuan et al., 2004] and Hulu Cave (purple) [Wang et al., 2001]. Smoothing using a low-pass filter of 750 years is shown in all the records (thick lines) from Figures 3c to 3f (except Pak et al. [2012] and Benway et al. [2006] $\delta^{18} \mathrm{O}_{\mathrm{SW}-\mathrm{IVC}}$ ) to highlight the main trends. Black arrows in Figures $3 \mathrm{c}, 3 \mathrm{f}$, and $3 \mathrm{~g}$ highlight the synchronization of the $16.1 \mathrm{ka}$ event in the records. Light purple vertical-boxed areas denote the cold periods, Younger Dryas (YD) and Heinrich Stadial 1 (HS1). Light green vertical-boxed area shows the BøllingAllerød (B-A) interstadial in the Northern Hemisphere.

[16] The G. bulloides $\mathrm{Mg} / \mathrm{Ca}$ and $U_{37}^{k}$-derived SST records at $34^{\circ} \mathrm{N}$ [Seki et al., 2002; Pak et al., 2012] show a steep deglacial warming of $4-5^{\circ} \mathrm{C}\left(U_{37}^{k}\right.$; Figure 3a, purple) and $7^{\circ}$ $\mathrm{C}(\mathrm{Mg} / \mathrm{Ca}$; Figure 3a, red), respectively. This is contrasted with the much reduced SST increase $\left(\sim 3^{\circ} \mathrm{C}\right)$ in the G. ruber SST record from SLB (Figure 3a, light blue) and $\sim 2.5^{\circ} \mathrm{C}$ in the alkenone record at $22^{\circ} \mathrm{N}$ (Figure 3a, yellow) [Herbert et al., 2001]. We consider that the amplitude of SST variability was much reduced in the southern sector of the California Margin (at SLB) because the warm SST at the onset of T1 that were maintained by the presence of warm tropical surface waters [Lynn and Simpson, 1987]. Muted SST decreases in the SLB during periods of extremely cold conditions in the Northern Hemisphere, such as YD and HS1 [e.g., Denton et al., 2010], and at $34^{\circ} \mathrm{N}$ (Figure 3a, red) [Pak et al., 2012], further confirm the persistent presence of warm waters at the core site.

[17] The G. bulloides-SST record at $25^{\circ} \mathrm{N}$ in the SLB (Figure 3a, dark blue) only spans the last $14 \mathrm{ky}$, but it shows a cooling trend toward the Holocene that contrasts with an 
expected warming linked to the global transition from the LGM to Holocene [Marchitto et al., 2010]. G. ruber $\mathrm{Mg} / \mathrm{Ca}$ reconstruction also features a cooling trend across the Earlyto-Middle Holocene at the same location (Figure 3a, light blue), although less pronounced probably due to spotty resolution. This cooling weakened the north to south SST gradient between the $G$. bulloides-SST profiles at $34^{\circ} \mathrm{N}$ (Figure $3 \mathrm{a}$, red) and $25^{\circ} \mathrm{N}$ (Figure $3 \mathrm{a}$, dark blue), suggesting a stronger advection of cooler California Current waters [Lynn and Simpson, 1987] to SLB since the early Holocene. Furthermore, we observe an increase in the temperature gradient between SLB (Figure 3a, light blue) and a core located further south at $22^{\circ} \mathrm{N}$ (Figure 3a, yellow) [Herbert et al., 2001], delimiting the southern reach of the California Current somewhere between $25^{\circ} \mathrm{N}$ and $22^{\circ} \mathrm{N}$ during the Holocene.

[18] We propose two possible explanations for the data pattern observed. A stronger (weaker) influence of the California Current waters at the SLB is associated with the strengthening (weakening) of the northerly winds along the California Margin, due to the strengthening (weakening) of the land-ocean atmospheric pressure gradient that, in turn, is controlled by the relative magnitude and positioning of the NPH and continental low [Bakun, 1973]. The SST pattern we see suggests that the precessionally driven rise in insolation of Northern Hemisphere during T1 [Laskar et al., 2004], together with the retreat of the Laurentide and Cordilleran ice sheets [Carlson and Clark, 2012], could have led to the relaxation of the high-pressure cell over the North American continent. This intensified the northerly winds along the eastern Pacific margin, increasing the influence of California Current waters in the SLB toward the Holocene [COHMAP Members, 1988; Lyle et al., 1992]. This view agrees with the numerical models [Clement et al., 1999] simulating a weaker NPH during late marine oxygen isotope stage 2 [Yamamoto et al., 2007] associated with the precession minimum.

[19] Alternatively, the larger influence of warm and salty water masses at $25^{\circ} \mathrm{N}$ may be the local expression of the ENSO-like conditions in the Pacific Ocean. At present, during El Niño conditions subtropical gyre water masses are advected along the Southern California Current System [Durazo and Baumgartner, 2002] and even further north during more extreme events [Thunell et al., 1999; Bograd and Lynn, 2001]. It has been suggested that El Niño-like conditions persisted in the tropical Pacific up to $\sim 11 \mathrm{ka}$ B.P. [Koutavas et al., 2002] and were gradually replaced by a La Niña-like state [cf. Antinao and McDonald, 2013] by the mid-Holocene [Koutavas et al., 2006; Koutavas and Joanides, 2012]. Evidence for the latter at SLB is given by the cooling in the G. bulloides $-\mathrm{Mg} / \mathrm{Ca}$ record [Marchitto et al., 2010] (Figure 3a) and slight freshening (Figure 2d) during the Holocene, in response to the California Current intensification. Notably, the large North to South SST gradient along the California Margin (Figure 3a) during North Atlantic stadials due to the arrival of California Current water masses at $34^{\circ} \mathrm{N}$ [Pak et al., 2012] implies that other processes prevented the ENSO signal to spread to those latitudes during YD and HS1. This also highlights the complexity of using modern processes in isolation as analogues to explain past climatic changes along the California Margin [McClymont et al., 2012].

\subsection{Millennial-Scale Events at the SLB Across T1}

[20] Hydrographic changes in SLB across the Holocene have been proposed to reflect a solar activity modulation of ENSO [Marchitto et al., 2010]. Our analysis highlights the additional role played by the variability of the California Current in association with atmospheric developments over the North Pacific. The set of SST reconstructions in the California Margin presented in Figure 3a suggests strong influence of the tropical/subtropical water masses to the SLB during T1 at the expense of the California Current, with opposing developments across the Holocene. The G.ruber$\delta^{18} \mathrm{O}_{\mathrm{SW}-\mathrm{IVC}}$ profile from the SLB (Figure 3c, light blue) agrees well with coeval $\delta^{18} \mathrm{O}_{\mathrm{SW}-\mathrm{IVC}}$ reconstructions from the tropical Pacific Ocean (Figures 3d-3e) [Rosenthal et al., 2003; Benway et al., 2006; Leduc et al., 2007; Pena et al., 2008], corroborating our inference of a weaker California Current and larger influence of tropical/subtropical water masses to $25^{\circ} \mathrm{N}$ during $\mathrm{T} 1$. This is exemplified by the remarkably similar $\delta^{18} \mathrm{O}_{\mathrm{SW}-\mathrm{IVC}}$ shifts $(\sim 0.5-0.7 \%)$ in the eastern equatorial Pacific [Benway et al., 2006; Leduc et al., 2007] and SLB records during YD and HS1 (Figures 3c-3d). It further implies a fundamental change in the hydrologic cycle in the tropics reaching into the midlatitudes of the North Pacific.

[21] Glacial and deglacial millennial-scale $\delta^{18} \mathrm{O}_{\mathrm{SW}-\mathrm{IVC}}$ fluctuations in the tropical Pacific invoke changes in the mean position of the ITCZ (Figure 3f). Briefly, a southward shift in the mean position of the ITCZ in combination with the water vapor blocking effect by the Andes could have reduced moisture transport from the Atlantic-to-Pacific and increased salinity in the East Pacific during YD and HS1 (Figure 3e) [Leduc et al., 2007]. Likewise, the southward displacement of the ITCZ resulted in a weaker East Asian (summer) Monsoon [Yancheva et al., 2007], which likely promoted the salinification of western tropical Pacific [Rosenthal et al., 2003] during North Atlantic cold phases of the deglaciation (Figure 3f). Therefore, latitudinal migration of the ITCZ position provides the conditions under which salinity in the tropical Pacific changed during abrupt cold and warm, i.e., stadial and interstadial episodes in the Northern Hemisphere (Figures 3d-3e). In order to explain the salinity anomalies observed at SLB across T1, we propose that these salinity changes were consequently advected as far north as $25^{\circ} \mathrm{N}$ as ice sheet and/or ENSO-like conditions kept northerly winds along the California Margin relatively weak until the early Holocene.

[22] Alternatively, we propose another mechanism that involves a similar relation between the present ITCZ, NPH, and northerly winds to explain the millennial-scale $\delta^{18} \mathrm{O}_{\mathrm{SW}-\mathrm{IVC}}$ fluctuations we observe at the SLB. Briefly, the deglacial strengthening of the northerly winds coupled with the demise of the North American ice sheet could have been punctuated by periods of weakening during YD and HS1. At present, the strengthening (weakening) of the northerly winds that drive the California Current to the SLB during summer (winter) is linked to the northward (southward) position of the NPH and ITCZ [Walliser and Gautier, 1993; Checkley and Barth, 2009]. If this relationship held for YD and HS1, then the NPH would have moved southward along with the ITCZ (Figure 3f) [Deplazes et al., 2013] when cold conditions developed in the Northern Hemisphere. We propose that a displaced southward and 


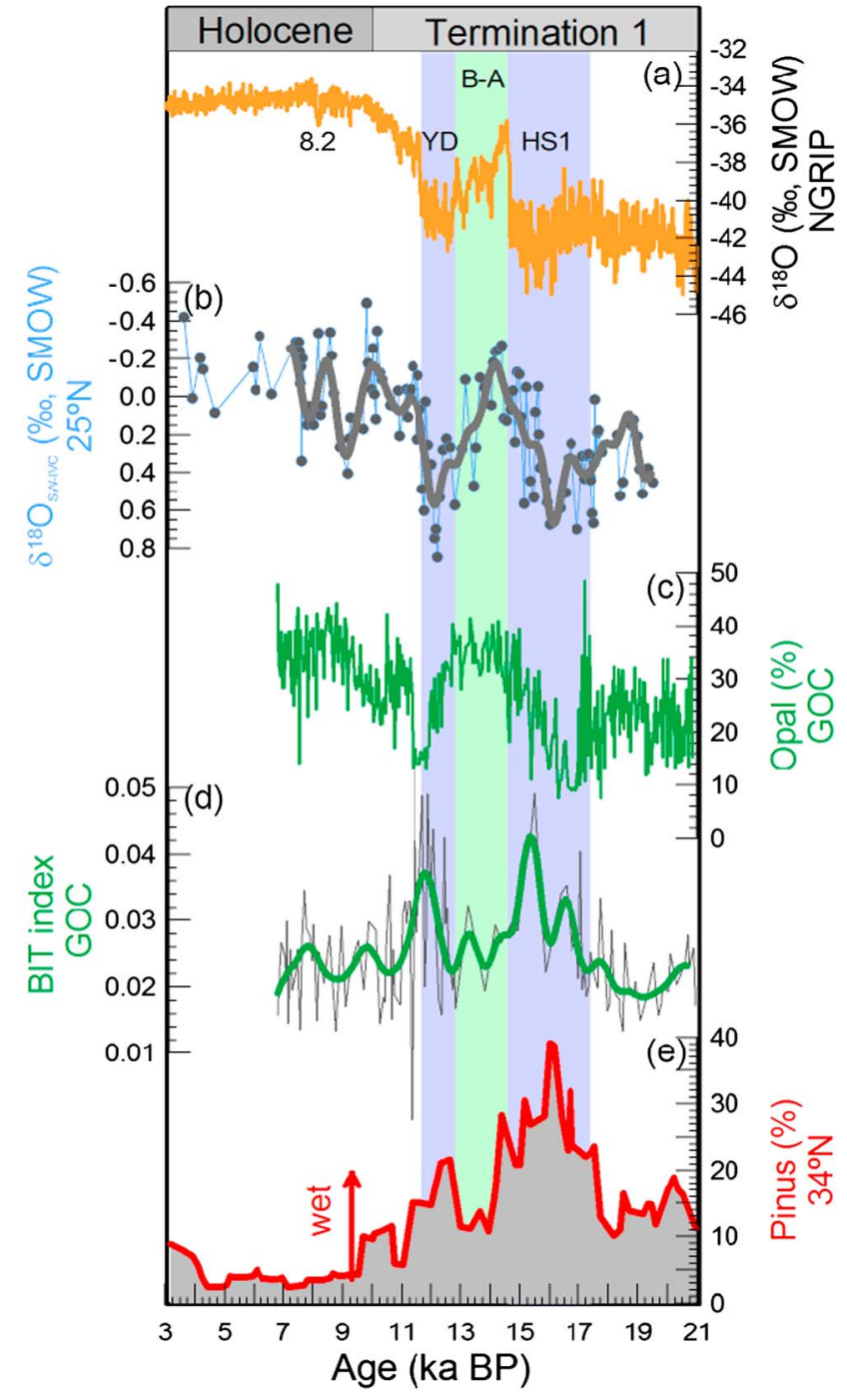

Figure 4. (a) $\delta^{18} \mathrm{O}$ in the NGRIP ice core record of Greenland is shown as reference [NGRIP members, 2004]. (b) Local $\delta^{18} \mathrm{O}_{\mathrm{SW}-\mathrm{IVC}}$ changes at MD02-2505 using G. ruber (in a broad sense). (c) Opal percentage and (d) Branched and Isoprenoid Tetraether (BIT) index from the Guaymas Basin in the Gulf of California (MD02-2515) [McClymont et al., 2012]. (e) Pinos percentage from Site ODP $893 \mathrm{~A}$ at $34^{\circ} \mathrm{N}$ [Heusser, 2000]. Smoothing using a low-pass filter of 750 years is shown in gray and red in Figures $4 \mathrm{~b}$ and $4 \mathrm{e}$, respectively, to highlight the main trends. Light purple vertical-boxed areas denote the cold periods, Younger Dryas (YD) and Heinrich Stadial 1 (HS1). Light green vertical-boxed area shows the Bølling-Allerød (B-A) interstadial in the Northern Hemisphere.

weakened NPH in combination with the relaxation of the high-pressure cell over the American continent [COHMAP member, 1988] weakened again the land to ocean pressure gradient along the California Margin during YD and HS1. This prevented cold and fresh surface conditions at $34^{\circ} \mathrm{N}$ [Pak et al., 2012] to be advected to the SLB in agreement with the SST and $\delta^{18} \mathrm{O}_{\mathrm{SW}-I V C}$ developments along the California Margin (Figures 3a and 3c). Weaker northerly winds during YD and HS1 are also consistent with a reduction of upwelling cells along the California Margin [Hendy et al., 2004] and with the idea that hydrographic changes at higher latitudes during stadials likely coincided with California Current cooling rather than changes in its strength [e.g. White et al., 2013].

[23] Our $\delta^{18} \mathrm{O}_{\text {SW-IVC }}$ record during HS1 displays a distinct two-phase structure, which has been recently identified in several paleoclimatic records [Broecker and Putnam, 2012], and marks a shift from saltier to fresher surface conditions at SLB at $16.2 \pm 0.8 \mathrm{ka}$ (at 95\% confidence level). This coincides - within chronological uncertainties - with the most pronounced southward displacement of the ITCZ in the Atlantic (Figure 3f, black arrow) [Deplazes et al., 2013] and with the weakest Asian Monsoon phase (Figure 3g, black arrow) [Wang et al., 2001] of the last $21 \mathrm{ky}$. Its occurrence in the Northeast Pacific suggests that this event featured an important reorganization of the low- to middle-latitude ocean-atmosphere system in the Pacific. Furthermore, the coincidence of this change with the intense North Atlantic cooling associated to Heinrich Event 1 [Bard et al., 2000] supports our contention of an atmospheric link between the North Atlantic and North Pacific, which probably involved the weakening of the NPH along with the southward migration of the ITCZ. In this sense, the Heinrich Event 1 at $16.1 \mathrm{ka}$ [Bard et al., 2000] can be regarded as the triggering factor not only for the well documented North-South seesaw across the Atlantic Ocean [Barker et al., 2009] but also for an effective transmission of the signal via the atmosphere to the Pacific Ocean.

\subsection{Climate Implications of the Northeast Pacific Millennial-Scale Atmospheric Changes}

[24] Different studies have provided evidence of major reorganizations of the atmospheric circulation over the California Margin during YD and HS1 [e.g., Mcclymont et al., 2012] in line with the tight coupling of Greenland stadials (Figure 4a), SLB salinification (Figure 4b), and ITCZ mean position fluctuations (Figure 3f) discussed above. Decreases in opal percentages (Figure 4c) and upwelling [McClymont et al., 2012] during YD and HS1 point to weaker northerly winds over the Gulf of California, coinciding with weaker influence of the California Current to the SLB and concomitant surface salinification (Figure 4b). Precipitation changes in the California Margin are tightly linked to processes that control the intensity of the California Current, i.e., the NPH and associated northerly winds. In winter (summer), the NPH weakens (strengthens) and allows westerly storms to enter the California Margin (higher latitudes), thereby increasing (decreasing) precipitation along the coast [Hickey, 1979; cf. Lyle et al., 2010; Antinao and McDonald, 2013]. It has been hypothesized that the presence of the large Cordilleran and Laurentide ice sheets during glacial periods caused the southward movement of the winter storm tracks, increasing precipitation along the west coast of North America during the LGM [COHMAP members, 1988] and North Atlantic stadials [Asmerom et al., 2010].

[25] However, Lyle et al. [2012] found that precipitation patterns in the Great Basin and the timing of wet periods along the California Margin do not fit this hypothesis. They proposed that deglacial millennial-scale precipitation patterns in the California Margin (Figures 4d-4e) originated 
from the weakening of the NPH and concomitant advection of tropical southerly air masses from the Pacific Ocean. Others [Robert, 2004; Lyle et al., 2010] have similarly hypothesized that precipitation patterns in the California Margin during T1 were associated to the advection of tropical waters linked to atmospheric circulation changes that involved the weakening of the California Current.

[26] The evidence reported here of an increase of the North $\left(34^{\circ} \mathrm{N}\right)$ to South $\left(25^{\circ} \mathrm{N}\right) \mathrm{SST}$ gradient during YD and HS1 can be reconciled with both hypotheses, as (a) it points to a weaker NPH associated with a substantial southward displacement of the ITCZ, and in turn, less California Current influence at $25^{\circ} \mathrm{N}$ and (b) suggests that tropical/subtropical waters were advected as far north as $25^{\circ} \mathrm{N}$ across $\mathrm{T} 1$. This atmospheric-oceanic configuration along the southern California Margin most likely increased humidity in the region. Thus, synchronicity of the hydrographic changes at $25^{\circ} \mathrm{N}$ (Figure $4 \mathrm{~b}$ ) with enhanced runoff at the Gulf of California as evidenced by high BIT index values (Figure 4d) and percentage of wet-adapted vegetation at $34^{\circ} \mathrm{N}$ (Figure 4e), collectively make a strong case that the source of precipitation along the California Margin may have been indeed the tropical Pacific [Antinao and McDonald, 2013].

\section{Conclusions}

[27] G. ruber (s.1.) SST and $\delta^{18} \mathrm{O}_{\mathrm{SW}-\mathrm{IVC}}$ records presented here from the SLB suggest that the oceanographic regime in this region experienced a fundamental change during the last deglaciation. During most of T1, the SLB was influenced by tropical/subtropical waters, while the Holocene was characterized by prominent advection of California Current waters (at least) as far south as $25^{\circ} \mathrm{N}$. These developments agree with an intensification of the northerly winds along the California Margin toward the Holocene in response to Northern Hemisphere ice sheet collapses during T1. The hydrographic changes in the SLB are also consistent with a transition from predominant El Niño-like (glacial) to $\mathrm{La}$ Niña-like (Holocene) conditions.

[28] North Atlantic stadials (YD and HS1) are recorded at the SLB as periods of high $\delta^{18} \mathrm{O}_{\mathrm{SW}-\mathrm{IVC}}$ in concordance with records from the tropical Pacific influenced by Asian Monsoon strength and Atlantic-to-Pacific humidity transport in association with ITCZ mean position changes. This suggests that millennial-scale variations at the SLB resulted from (a) the direct advection of tropical water masses across $\mathrm{T} 1$ at the expenses of the California Current or (b) California Current intense weakening during YD and HS1 superimposed on an overall strengthening of its influence to the SLB toward the Holocene. The latter could have resulted from a substantial weakening and southward displacement of the NPH in association with the southward migration of the ITCZ, which also corresponded with the weakening of the Asian summer Monsoon. A distinct switch from saltier to fresher conditions at $\sim 16.2 \mathrm{ka}$, during $\mathrm{HS} 1$, in the SLB coincides with the southernmost positioning of the ITCZ and with the weakest Asian Monsoon phase of the last 21 $\mathrm{ky}$, thereby corroborating our proposal for a strong coupling between these atmospheric features. Finally, the presence of tropical/subtropical water masses in the SLB, especially during YD and HS1, would have provided the additional source of moisture and explains the apparent mismatch between wet periods in the Great Basin and along the California Margin.

[29] Acknowledgments. The authors want to thank B. Acosta-Molina for helping in the early stages of foraminifera picking, and I. Villarroya and C. Cantero for ICP-MS analytical assistance. We are also grateful to G. Marino and G. Leduc for discussions and suggestions during manuscript preparation. I. Cacho, R. Zeebe, U. Ninnemann, and E. McClymont are thanked for commenting on early versions of this study. M. Yamamoto and an anonymous reviewer are thanked for insightful comments and suggestions during the review process. This is Past4Future contribution no. 56. The research leading to these results has received funding from the European Union's Seventh Framework Programme (FP7/2007-2013) under grant agreement 243908, "Past4Future. Climate change-Learning from the past climate." We also acknowledge to CONACYT grants G35229-T, SEP04-C01-46152, and CB-2009-01-130095, O0C091.

\section{References}

Antinao, J. L., and E. McDonald (2013), An enhanced role for the Tropical Pacific on the humid Pleistocene Holocene transition in southwestern North America, Quat. Sci. Rev., doi:10.1016/j.quascirev.2013.03.019.

Asmerom, Y., V. Polyak, and S. Burns (2010), Variable winter moisture in the southwestern United States linked to rapid glacial climate shifts, Nat. Geosci., 3, 114-117, doi:10.1038/ngeo 754.

Bakun, A. (1973), Coastal upwelling indices, west coast of North America, 1946-71, Technical Report NMFS SSRF-671, NOAA.

Bard, E., F. Rostek, J. L. Turon, and S. Gendreau (2000), Hydrological impact of Heinrich events in the subtropical northeast Atlantic, Science, 289, 1321-1324.

Barker, S., M. Greaves, and H. Elderfield (2003), A study of cleaning procedures used for foraminiferal $\mathrm{Mg} / \mathrm{Ca}$ paleothermometry, Geochem. Geophys. Geosyst., 4(9), 8407, doi:10.1029/2003GC000559.

Barker, S., P. Diz, M. J. Vautravers, J. Pike, G. Knorr, I. R. Hall, and W. S. Broecker (2009), Interhemispheric Atlantic seesaw response during the last deglaciation, Nature, 457, 1097-1102.

Behl, R. J., and J. P. Kennett (1996), Evidence for brief interstadial events in the Santa Barbara Basin, NE Pacific during the past $60 \mathrm{Kyr}$, Nature, 379, 243-246.

Bemis, B. E., H. J. Spero, J. Bijma, and D. W. Lea (1998), Reevaluation of the oxygen isotopic composition of planktonic foraminifera: Experimental results and revised paleotemperature equations, Paleoceanography, 13, 150-160.

Benway, H. M., A. C. Mix, B. A. Haley, and G. P. Klinkhammer (2006), Eastern Pacific Warm Pool paleosalinity and climate variability: 0-30 kyr, Paleoceanography, 21, PA3008, doi:10.1029/2005PA00120.

Berger, R., R. E. Taylor, and W. F. Libby (1966), Radiocarbon content of marine shells from the California and Mexican west coast, Science, 153, 864-866.

Bograd, S., and R. J. Lynn (2001), Physical-biological coupling in the California Current during the 1997-99 El Niño-La Niña cycle, Geophys. Res. Lett., 28, 275-278.

Boyle, E. A. (1983), Manganese carbonate overgrowths on foraminifera tests, Geochim. Cosmochim. Acta, 47, 1815-1819, doi:10.1016/00167037(83)90029-7.

Broecker, W. S., and A. E. Putnam (2012), How did the hydrologic cycle respond to the two-phase mystery interval?, Quat. Sci. Rev., 57, 17-25.

Carlson, A. E., and P. U. Clark (2012), Ice-sheet sources of sea-level rise and freshwater discharge during the last deglaciation, Rev. Geophys., 50, RG4007, doi:10.1029/2011RG000371.

Checkley, D. M., and J. A. Barth (2009), Patterns and processes in the California Current System, Prog. Oceanogr., 83, 49-64, doi:10.1016/j. pocean.2009.07.028.

Cheshire, H., J. Thurow, and A. J. Nederbragt (2005), Late Quaternary climate change record from two long sediment cores from Guaymas Basin, Gulf of California, J. Quat. Sci., 20, 457-469.

Clark, P. U., et al. (2012), Global climate evolution during the last deglaciation, Proc. Natl. Acad. Sci. U. S. A., 109(19), E1134-E1142.

Clement, A. C., R. Seager, and M. A. Cane (1999), Orbital controls on the El Niño/Southern Oscillation and the tropical climate, Paleoceanography, 14, 441-456.

Cooperative Holocene Mapping Project (COHMAP) Project Members (1988), Climatic changes of the last 18,000 years: Observations and model simulations, Science, 241, 1043-1052, doi:10.1126/ science. 241.4869 .1043

Dansgaard, W., et al. (1993), Evidence for general instability of past climate from a 250-kyr ice-core record, Nature, 364, 218-220, doi:10.1038/ $364218 \mathrm{a} 0$. 
Dekens, P. S., D. W. Lea, D. K. Pak, and H. J. Spero (2002), Core top calibration of $\mathrm{Mg} / \mathrm{Ca}$ in tropical foraminifera: Refining paleotemperature estimation, Geochem. Geophys. Geosyst., 3(4), 1022, doi:10.1029/ $2001 \mathrm{GC} 000200$

Denton, G. H., R. F. Anderson, J. R. Toggweiler, R. L. Edwards, J. M. Schaefer, and A. E. Putnam (2010), The last glacial termination, Science, 328, 1652-1656.

Deplazes, G., et al. (2013), Links between tropical rainfall and North Atlantic climate during the last glacial period, Nat. Geosci., 6, 213-217, doi:10.1038/ngeo1712.

de Villiers, S., M. Greaves, and H. Elderfield (2002), An intensity ratio calibration method for the accurate determination of $\mathrm{Mg} / \mathrm{Ca}$ and $\mathrm{Sr} / \mathrm{Ca}$ of marine carbonates by ICP-AES, Geochem. Geophys. Geosyst., 3(1), 1001, doi:10.1029/2001GC000169.

Durazo, R., and T. R. Baumgartner (2002), Evolution of oceanographic conditions off Baja California: 1997-1999, Prog. Oceanogr., 54, 7-31.

Ganeshram, R. S., and T. F. Pedersen (1998), Glacial-interglacial variability in upwelling and bioproductivity off NW Mexico: Implications for Quaternary palaeoclimate, Paleoceanography, 13, 634-645.

Greaves, M., et al. (2008), Interlaboratory comparison study of calibration standards for foraminiferal $\mathrm{Mg} / \mathrm{Ca}$ thermometry, Geochem. Geophys. Geosyst., 9, Q08010, doi:10.1029/2008GC001974.

Hendy, I. L. (2010), The paleoclimatic response of the Southern Californian Margin to the rapid climate change of the last $60 \mathrm{ka}$ : A regional overview, Quat. Int., 215, 62-73.

Hendy, I. L., and J. P. Kennett (2000), Dansgaard/Oeschger Cycles and the California Current System: Planktonic foraminiferal response to rapid climate change in Santa Barbara Basin, ODP Hole 893A, Paleoceanography, 15, 30-42.

Hendy, I. L., T. F. Pedersen, J. P. Kennett, and R. Tada (2004), Intermittent existence of a southern Californian upwelling cell during submillennia climate change of the last $60 \mathrm{kyr}$, Paleoceanography, 19, PA3007, doi:10.1029/2003PA000965.

Herbert, T. D., J. D. Schuffert, D. Andreasen, L. Heusser, M. Lyle, A. Mix, A. C. Ravelo, L. Stott, and J. C. Herguera (2001), Collapse of the California Current during glacial maxima linked to climate change on land, Science, 293, 71-76.

Heusser, L. E. (2000), Rapid oscillations in western North America vegetation and climate during oxygen isotope stage 5 inferred from pollen data from Santa Barbara Basin (Hole 893A), Palaeogeogr. Palaeoclimatol. Palaeoecol., 161, 407-421, doi:10.1016/S0031-0182(00)00096-1.

Hickey, B. M. (1979), The California Current System hypotheses and facts, Prog. Oceanogr., 8(4), 191-279, doi:10.1016/0079-6611(79)90002-8.

Koutavas, A., and S. Joanides (2012), El Niño-Southern Oscillation extrema in the Holocene and Last Glacial Maximum, Paleoceanography, 27, PA4208, doi:10.1029/2012PA002378.

Koutavas, A., J. Lynch-Stieglitz, T. M. Marchitto Jr., and J. P. Sachs (2002), El Niño-like pattern in ice age tropical Pacific sea surface temperature, Science, 297, 226-230, doi:10.1126/science.1072376.

Koutavas, A., P. B. deMenocal, G. C. Olive, and J. Lynch-Stieglitz (2006), Mid-Holocene El Niño-Southern Oscillation (ENSO) attenuation revealed by individual foraminifera in eastern tropical Pacific sediments, Geology, 34, 993-996, doi:10.1130/G22810A.1.

Laskar, J., P. Robutel, F. Joutel, M. Gastineau, A. C. M. Correia, and B. Levrard (2004), A long term numerical solution for the insolation quantities of the Earth, Astron. Astrophys., 428, 261-285.

Leduc, G., L. Vidal, K. Tachikawa, F. Rostek, C. Sonzogni, L. Beaufort, and E. Bard (2007), Moisture transport across Central America as a positive feedback on abrupt climatic changes, Nature, 445, 908-911.

LeGrande, A. N., and G. A. Schmidt (2006), Global gridded data set of the oxygen isotopic composition in seawater, Geophys. Res. Lett., 33, L12604, doi:10.1029/2006GL026011.

Linacre, L., R. Durazo, J. M. Hernández-Ayón, F. Delgadillo-Hinojosa G. Cervantes-Díaz, J. R. Lara-Lara, V. Camacho-Ibar, A. Siqueiros-Valencia and C. Bazán-Guzmán (2010), Temporal variability of the physical and chemical water characteristics at a coastal monitoring observatory: Station ENSENADA, Cont. Shelf Res., 30, 1730-1742.

Lyle, M., R. Zahn, F. Prahl, J. Dymond, R. Collier, N. Pisias, and E. Suess (1992), Paleoproductivity and carbon burial across the California Current: The MULTITRACERS Transect, $42^{\circ} \mathrm{N}$, Paleoceanography, 7 , 251-272, doi:10.1029/92PA00696.

Lyle, M., L. Heusser, C. Ravelo, D. Andreasen, A. Olivarez Lyle, and N. Diffenbaugh (2010), Pleistocene water cycle and eastern boundary current processes along the California continental margin, Paleoceanography, 25, PA4211, doi:10.1029/2009PA001836.

Lyle, M., L. Heusser, C. Ravelo, M. Yamamoto, J. Barron, N. S. Diffenbaugh, T. Herbert, and D. Andreasen (2012), Out of the Tropics: The Pacific, Great Basin Lakes, and Late Pleistocene water cycle in the Western United States, Science, 337, 1629-1633, doi:10.1126/ science. 1218390 .
Lynn, R. J., and J. J. Simpson (1987), The California current system: The seasonal variability of physical characteristics, J. Geophys. Res., 92, $12,947-12,966$

Marchitto, T. M., R. Muscheler, J. D. Ortiz, J. D. Carriquiry, and A. van Geen (2010), Dynamical response of the tropical Pacific Ocean to solar forcing during the Early Holocene, Science, 330, 1378-1381.

McClymont, E. L., R. S. Ganeshram, L. E. Pichevin, H. M. Talbot, B. E. van Dongen, R. C. Thunell, A. M. Haywood, J. S. Singarayer, and P. J. Valdes (2012), Sea-surface temperature records of Termination 1 in the Gulf of California: Challenges for seasonal and interannual analogues of tropical Pacific climate change, Paleoceanography, 27, PA2202, doi:10.1029/2011PA002226.

Mortyn, P. G., J. C. Herguera, and M. A. Martínez-Botí (2011), Instrumental validation of Globigerinoides ruber $\mathrm{Mg} / \mathrm{Ca}$ as a proxy for NE Pacific summer SST, Geophys. Res. Lett., 38, L16601, doi:10.1029/2011GL047803.

North Greenland Ice Core Project (NGRIP) Members (2004), High-resolution record of Northern Hemisphere climate extending into the last interglacial period, Nature, 431, 147-151, doi:10.1038/nature02805.

Pak, D. K., D. W. Lea, and J. P. Kennett (2012), Millennial scale changes in sea surface temperature and ocean circulation in the northeast Pacific, 10 60 kyr BP, Paleoceanography, 27, PA1212, doi:10.1029/2011PA002238.

Pena, L. D., I. Cacho, P. Ferretti, and M. A. Hall (2008), El NiñoSouthern Oscillation-like variability during glacial terminations and interlatitudinal teleconnections, Paleoceanography, 23, PA3101, doi:10.1029/2008PA001620.

Reimer, P. J., et al. (2009), INTCAL09 and MARINE09 radiocarbon age calibration curves, 0-50,000 years cal BP, Radiocarbon, 51, 1111-1150.

Robert, C. (2004), Late Quaternary variability of precipitation in Southern California and climatic implications: Clay mineral evidence from the Santa Barbara Basin, ODP Site 893, Quat. Sci. Rev., 23, 1029-1040.

Rosenthal, Y., D. W. Oppo, and B. K. Linsley (2003), The amplitude and phasing of climate change during the last deglaciation in the Sulu Sea, western equatorial Pacific, Geophys. Res. Lett., 30(8), 1428 , doi:10.1029/2002GL016612.

Sautter, L. R., and R. C. Thunell (1991), Seasonal variability in the $\delta 180$ and $\delta 13 \mathrm{C}$ of planktonic foraminifera from an upwelling environment: Sediment trap results from the San Pedro Basin, Southern California Bight, Paleoceanography, 6, 307-334.

Schrag, D. P., J. F. Adkins, K. McIntyre, J. L. Alexander, D. A. Hodell, C. Charles, and J. F. McManus (2002), The oxygen isotopic composition of seawater during the Last Glacial Maximum, Ouat. Sci. Rev., 21(1-3), 331-342, doi:10.1016/S0277-3791(01)00110-X.

Seki, O., R. Ishiwatari, and K. Matsumoto (2002), Millennial climate oscillations in NE Pacific surface waters over the last 82 kyr: New evidence from alkenones, Geophys. Res. Lett., 29(23), 2144 doi:10.1029/2002GL015200.

Stanford, J. D., R. Hemingway, E. J. Rohling, P. G. Challenor, M. Medina-Elizalde, and A. J. Lester (2011), Sea-level probability for the last deglaciation: A statistical analysis of far-field records, Global Planet. Change, 79, 193-203.

Steinke, S., H.-Y. Chiu, P.-S. Yu, C.-C. Shen, L. Löwemark, H.-S. Mii, and M.-T. Chen (2005), Mg/Ca ratios of two Globigerinoides ruber (white) morphotypes: Implications for reconstructing past tropical/subtropical surface water conditions, Geochem. Geophys. Geosyst., 6, Q11005, doi:10.1029/2005GC000926.

Steinke, S., M. Kienast, J. Groeneveld, L.-C. Lin, M.-T. Chen, and R. Rendle-Bühring (2008), Proxy dependence of the temporal pattern of deglacial warming in the tropical South China Sea: Toward resolving seasonality, Quat. Sci. Rev., 27(7-8), 688-700.

Thunell, R. C., and P. G. Mortyn (1995), Glacial climate instability in the northeast Pacific Ocean, Nature, 376, 504-506, doi:10.1038/376504a0.

Thunell, R., E. Tappa, C. Pride, and E. Kincaid (1999), Sea-surface temperature anomalies associated with the 1997-1998 El Niño recorded in the oxygen isotope composition of planktonic foraminifera, Geology, 27, 843-846.

van Geen, A., Y. Zheng, J. M. Bernhard, K. G. Cannariato, J. Carriquiry, W. E. Dean, B. W. Eakins, J. D. Ortiz, and J. Pike (2003), On the preservation of laminated sediments along the western margin of North America, Paleoceanography, 18(4), 1098, doi:10.1029/2003PA000911.

Walliser, D. E., and C. Gautier (1993), A satellite-derived climatology of the ITCZ, J. Clim., 6, 2162-2174.

Wang, Y. J., H. Cheng, R. L. Edwards, Z. S. An, J. Y. Wu, C.-C. Shen, and J. A. Dorale (2001), A high-resolution absolute-dated late Pleistocene monsoon record from Hulu Cave, China, Science, 294, 2345-2348.

Wang, X., A. S. Auler, R. L. Edwards, H. Cheng, E. Ito, Y. Wang, X. Kong, and M. Solheid (2007), Millennial-scale precipitation changes in southern Brazil over the past 90,000 years, Geophys. Res. Lett., 34, L23701, doi:10.1029/2007GL031149.

White, S. M., T. M. Hill, J. P. Kennett, R. J. Behl, and C. Nicholson (2013), Millennial-scale variability to $735 \mathrm{ka}$ : High-resolution climate records 


\section{RODRÍGUEZ-SANZ ET AL.: CALIFORNIA MARGIN CLIMATE VARIABILITY}

from Santa Barbara Basin, CA, Paleoceanography, 28, 213-226, doi:10.1002/palo.20022.

Yamamoto, M., M. Yamamuro, and Y. Tanaka (2007), The California current system during the last 136,000 years: Response of the North Pacific High to precessional forcing, Quat. Sci. Rev., 26, 405-414, doi:10.1016/j.quascirev.2006.07.014.

Yancheva, G., N. R. Nowaczyk, J. Mingram, P. Dulski, G. Schettler, J. F. W. Negendank, J. Liu, D. M. Sigman, L. C. Peterson, and
G. H. Haug (2007), Influence of the intertropical convergence zone on the East Asian monsoon, Nature, 445(7123), 74-77.

Yu, J., J. Day, M. Greaves, and H. Elderfield (2005), Determination of multiple element/calcium ratios in foraminiferal calcite by quadrupole ICP-MS, Geochem. Geophys. Geosyst., 6, Q08P01, doi:10.1029/ 2005GC000964.

Yuan, D., et al. (2004), Timing, duration, and transitions of the Last Interglacial Asian monsoon, Science, 304(5670), 575-578. 